\title{
Clean Cane Production Techniques and Environmental Sustainablility:
} A Review

\author{
Doorasamy Mishelle ${ }^{1}$ \\ ${ }^{1}$ School of Accounting, Economics and Finance, University of KwaZulu-Natal, South Africa \\ Correspondence: Doorasamy Mishelle, School of Accounting, Economics and Finance, University of \\ KwaZulu-Natal, South Africa. E-mail: Doorasamym@ukzn.ac.za
}

Received: April 19, 2017

Accepted: July 18, 2017 Online Published: September 29, 2017

doi:10.5539/jsd.v10n5p44

URL: https://doi.org/10.5539/jsd.v10n5p44

\begin{abstract}
Given the importance of sugar to humanity, clean cane production has become a source of concern for both academic and producers alike. Focusing on the largest producing and exporting countries of processed and refined sugarcane is the most appropriate means of understanding the concepts evolving around clean cane production. Climate change has not directly reduced the quantity of clean cane produced due to an increase in use of chemical products in farming for sugar cane, but has negatively affected the quality of output. Disease prevalence in harvested cane as well as high soil erosion from global warming have been key elements of the sudden decline in quality cane harvesting and processing. This decline in quality has not only reduce the amount of revenue accruable to farmers but with the consequence of future production prospect if improperly addressed. This study carried out a desk research methodology to review extant literature to identify contemporary issues that needs to be urgently researched on. While a number of issues were uncovered by this study, it was found that scientific experiments and mathematical models enhance theoretical facts on successful and disease free clean cane production methods. But due to the practicability exceptions and the inherent limitations in outcomes of experiments, the research stresses on the importance of field work through observations before theoretical assessments on the findings and the causes of disease prevalence and quality decline in output. This is hoped will sanitize the cane production process and output for the present and future generations.
\end{abstract}

Keywords: climate change, clean cane production, global warming, harvesting, and processing

\section{Introduction}

This study reviewed related literature and models of sugarcane production with the view to juxtapose traditional and modern ways of production. It particularly set out to ascertain that a decline in further research into alternative cultivation methods of sugarcane can have a negative impact in short term yield, as a result of new and rapid spread in crop diseases from intensive nitrogen fertilizer usage and poor trash removal techniques. Ignoring research into harvesting methods using modern machinery to separate trash can likely degrade the quality of the soil moisture as burning during manual harvesting would continue to be practiced.

Though Brazil is the largest producer of sugar cane in the world, it is important to look at other cane production strategies used in non-tropical regions of the world (Moreira et al., 2016). The methods of harvesting used are slightly different from hot humid tropical regions. Singels et al. (1999) as quoted by Loubser (2002) modelled a process of biomass and sucrose production during selected climate effects and irrigation procedures. The times of harvesting, are important, since seasons vary in these different regions of the world. Soil quality and texture, topography and natural disasters have profoundly affected the production of clean cane. (have to look deeper into the implications of time to harvest and show that research still needs to be done on it).

The shortcomings faced in applying scientific concepts in the research of clean cane production by Phil \& Terry (2003) in Australia, paved the way for future scientific input on models that can better help relate climate change to clean cane production. Exploring how genetic composition of sugarcane harvested can better be integrated in the search for disease free cultivation methods in India and Brazil is still lacking. The spread of disease as extreme climatological factors can lead to yield decline.

The research findings could contribute to sustainable sugarcane harvesting and processing for production of biofuels. In order to outweigh the impact of environmental disaster and climate change on steady production 
increases, this research work focused more on exposing the main gaps in factors that were identified to have a negative impact on clean cane harvesting. And hence contribute to the body of subsisting literature by highlighting key gaps and further research areas that are critical to the future of cane production in the light of environmental sustainability. The study exploited an exploratory research method to analyze previous empirical works and models in this area on which the findings were predicated. Going forward, in section 2.0 is the main review that constitute the crux of the work while in section 3.0 is the summary and conclusion.

\section{Models and Extant Literature Review}

According to Moreira et al. (2016: 58), sugarcane production has increased from 2013 to 2016 with Brazil accounting for $25 \%$ of the worlds output, followed by India (11.5\% of total output), China and Thailand (less than $10 \%$ of output) as the four largest producers of sugarcane. A consumption decline in processed sugar as a result of research findings on its health implications have not affected increasing levels of production, as by-products are used in producing sugarcane ethanol and bioelectricity, which have become increasingly acceptable as alternative sources of clean and renewable energy (Richard, 2005). The environmental impact of the traditional methods still used in producing sugarcane through burning prior to harvesting cannot be ruled out as $80 \%$ of all harvested sugarcane is done manually in India and Brazil. Irrespective of the method of harvesting used, research conducted in Argentina by Meyer (2005) could prove that recoverable sucrose (from chemical processing) in refined sugarcane is lost. Meyer et al., (2005) as quoted by Richards (2005: 504) failed to elaborate on why trash removal in unburnt cane harvesting is important, nor provide facts of the deterioration which occurs during the burning of harvested cane. This still left a research gap in identifying why the switch from manual cane harvesting to green cane harvesting and processing could pose future environmental threats and increased production costs. The table below illustrates the outcome of the transition from the traditional method of manual cane harvesting to some greener mechanized method in Mauritius.

Table 1. Burnt vs. green cane. Chopper harvested fuel consumption

\begin{tabular}{lcc}
\hline & Green cane & Burnt cane \\
\hline Tonnes cane harvested & 269,887 & 70,375 \\
Fuel used (litres) & 319,107 & 72,996 \\
Fuel consumption (L/tonne) & 1.18 & 1.04 \\
\hline
\end{tabular}

Source: Richard (2005)

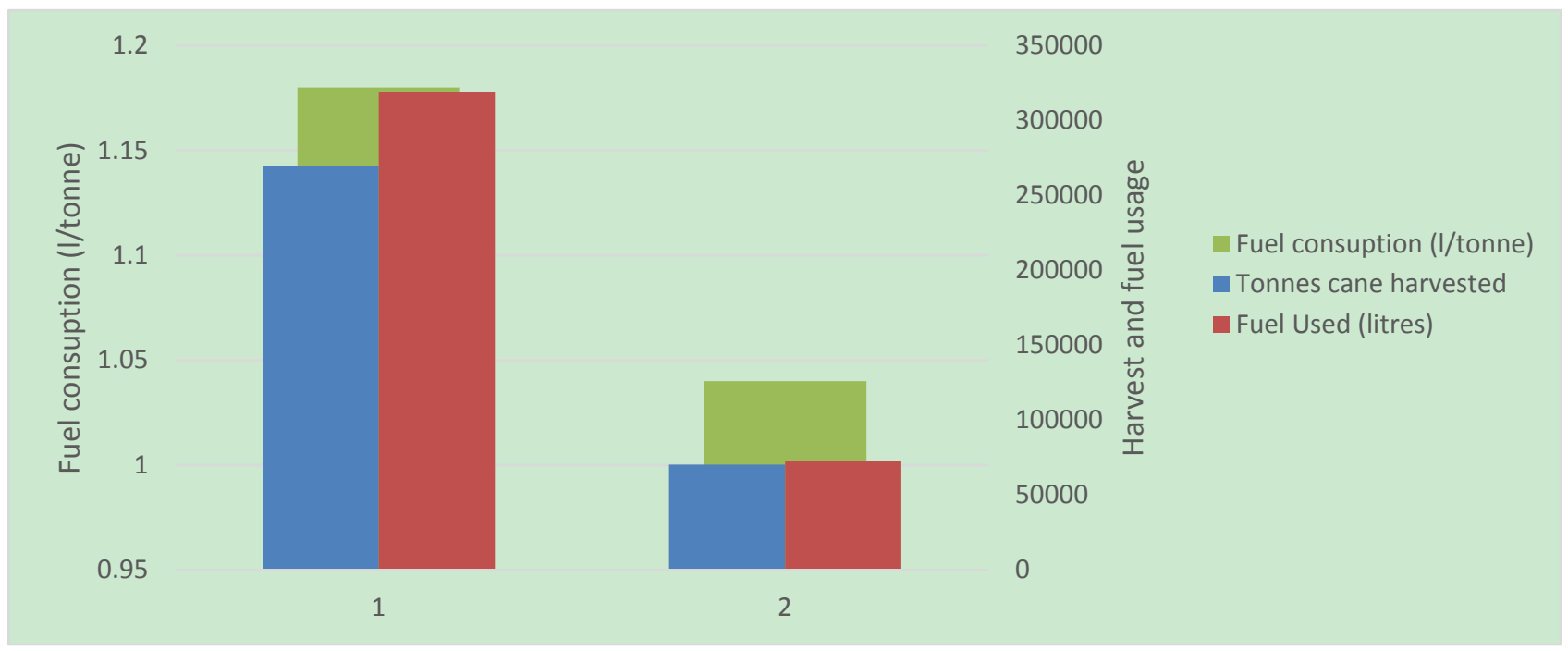

Figure 1. Burnt versus green cane fuel consumption

Figure 1 explains the obvious distinctions between burnt and green harvest in terms of fuel consumption. It reflects the fact that green harvest seems to consume more fuel that is less environmental friendly than burnt harvest which apparently negates the principles of green accounting. This area need would need to be explored in 
research.

Though facts from data captured above in Mauritius in 2004 have proven that green cane mechanized harvesting process is costly, it didn't give enough evidence to support De Beer's research (1989) in South Africa which concluded that exclusion of cane residuals, when transporting harvests to factory could save vehicle loading costs. This would still be relevant to todays expected setbacks in harvesting and processing sugarcane as the mechanization and transportation are cost efficient but pollution levels are rising.

When looking at clean cane processing, the researcher cannot rule out the fact that increased climate change effects have negatively affected the processing of sugarcane. Minimizing agronomic problems through trash burn is not sustainable, as it instead increases agronomic problems. Meyer and Fenwick (2003), as quoted by Lyn et al., (2007: 168) explored the relationship between new harvesting systems and productivity improvements in South Africa's IIIovo sugar company. Spreading and raking of trash during sugarcane harvesting has eliminated conventional cultural practices like handpicking and burning, but the use of new technology like modified road brushes, has been proven to be more efficient (Loubser, 2002: 42). After looking at the wide variety of sugarcane in Brazil, Lobser (2002:44) concluded that the "time of harvest", "ratoon" and the "age of a cane" would play essential roles in influencing the harvesting of sugarcane. The negative relationship between burning of cane and its immediate deterioration impact was evident. His research went further to elaborate this relationship by using regression analysis to define the relation between deterioration and delays. Improving yields in the long term implies reducing the delays from harvesting to crushing of canes (Wood, 1976; Thomson \& Dick 1990). Though Wood (1976: 13) looked in the quicker deterioration of chopped cane over whole stalked cane, the research used only 5 varieties of ratoon cane (NCo 376, NCo 382, N51/168, N53/216 and N50/211), not older than 18 months. The random selection did not indicate specifically if equal proportion of stalked canes were used to conduct the research, for the sample of 280 selected. The number of bundles retained for testing in juice quality were only 16 bundles, while 12 bundles got chopped into $40 \mathrm{~cm}$ and $20 \mathrm{~cm}$ long, bundled and analyzed also for juice quality. This section was not proportionate to the total sample size, raising questions on the materiality of the outcome on the entire sample selected. The ratoon stunning diseases which could affect stunned canes wasn't looked into at the time of selection due to lack of extensive research in the quality of the sample. More recent research conducted by Sharon \& McFarlane (2003: 9) gave more credence to implications of ratoon stunning disease. The distinguishing characteristics of the disease in sugarcane could not be ruled out. The breakdown of sugarcane resistance which had previously been allopolyploid in nature would compromise the quality of the harvested green cane. Bailey and McFarlane (1999) and Rutherford et al., (2003) as quoted by Sharon \& McFarlane (2003), did estimate that ratoon stunning disease had resulted in a $1 \%$ percent decrease in South Africa's industrial output levels and up to $20 \%$ decrease for other African countries producing and processing sugarcane. Though the research focused on scientific methods of testing and reducing ratoon stunning diseases, it failed to lay emphases on how climate change has affected the quality of cultivating and processing clean cane in tropical and humid equatorial regions. Philip \& Terry (2003) took seasonal factors into consideration in Australia when conducting an experiment in Kalamia sugar mill estate near Queensland. Clones of sugarcane were planted of land previously fallowed for 6 months, with emphasis on the importance of reducing irrigation frequency at most favorable planting season (between May and June in Australia). While measuring stalks numbers for sampling using heights of close to $1 \mathrm{~m}$, the research stressed on genotype and environmental interactions as essential factors affecting the quality of harvested clean cane, but fell short of sufficient evidence to prove the relationship it tried to define in the experiment conducted. The adverse relationship between Irrigation and precipitation levels were important variables in seasonal cultivation and harvesting of green cane. 
Table 2 - Rainfall $(\mathrm{mm})$ for Expts 1 and 2 periods from planting

Irrigation frequency (number per month) is indicated for months in which irrigation frequency differe between irrigation treatments

\begin{tabular}{|l|c|c|c|c|c|c|}
\hline Months & Rainfall & $\begin{array}{c}\text { Expt1 } \\
\text { control }\end{array}$ & $\begin{array}{c}\text { Restricted } \\
\text { irrigation }\end{array}$ & Rainfall & $\begin{array}{c}\text { Expt 2 } \\
\text { control }\end{array}$ & $\begin{array}{c}\text { Restricted } \\
\text { irrigation }\end{array}$ \\
\hline Apr.-Sept & 149.5 & & & 122.1 & & \\
\hline Oct & 55.7 & & & 52.2 & & \\
\hline Nov & 30.7 & & & 7.3 & 3 & 0 \\
\hline Dec & 33.2 & 4 & 0 & 319.3 & & \\
\hline Jan & 283 & 1 & 0 & 242.4 & & \\
\hline Feb & 18.8 & 1 & 0 & 170.5 & & \\
\hline Mar & 6.2 & 2 & 0 & 35.5 & & \\
\hline Apr & 47 & 2 & 1 & 65.4 & & \\
\hline May & 12.1 & & & 88.2 & & \\
\hline Jun & 6.9 & & & 11.1 & & \\
\hline Jul & 5.1 & & & 18.9 & & \\
\hline Aug & 14.6 & & & 29.3 & & \\
\hline
\end{tabular}

Source: Jackson and Morgan (2003)

The 3 most favorable sampling times as above were March, May and June (with lowest precipitation levels). The experiment results showed moderate reduction in sugarcane yields, though a lack of sufficient input to prove the genetic variance component was used correctly. Relative sampling experiments conducted on soybeans by Johnson, Robinsons \& Comstock (1955), described the hereditary estimates when using variance and estimating methods for soybean research as cumbersome, since gene effects were considered additive at the time of the research. Sampling error and hereditary units' nature (plot, plant, mean of plots etc.,) do influence magnitudes of hereditary estimates. The formula used for the data analysis of sugarcane clone reparability (SCR) and sampling time(ST) in Australia is illustrated below;

Source of variation

Expectation of mean square

Clones

$$
\sigma_{e b}^{2}+n_{b}-n_{t}-n_{i}-\sigma_{c}^{2}
$$

Clone x irrigation treatment interaction $\sigma_{e b}^{2}+n_{b}-n_{t}-\sigma_{c i}^{2}$

Error b

$$
\sigma_{e b}^{2}
$$

Clone $\mathrm{x}$ time interaction

$$
\sigma_{e}^{2}+n_{b}-n_{i} \cdot \sigma_{c t}^{2}
$$

Clone $\mathrm{x}$ irrigation $\mathrm{x}$ time interaction $\sigma_{e}^{2}+n_{b}-\sigma_{\text {cit }}^{2}$

Error e

$$
\sigma_{e}^{2}
$$

So that

$$
\mathrm{CR}=\frac{\sigma_{\mathrm{e}}^{2}}{\left(\sigma_{\mathrm{e}}^{2}+\frac{\sigma_{\mathrm{e}}^{2}}{2}\right)}
$$

Where $\sigma_{e}^{2}$ is the genetic area component.

Ignoring these relevant factors in the research findings by Philip \& Terry (2003: 391) proves the outcome was inaccurate from inclusion of genetic variance in the regression formula used above. Meaningful comparison cannot be achieved when phenotypic expressions result from genetic effects that ignore genotype-environmental interactions arising from sample selection. Yang et al., (2013: 100) came up with evidence that Mixed linear models(MLM) would emerge as a preferred method for conducting empirical studies in genetic association in humans and other organisms like sugarcane used for the current study.

For linear regression (LR), the expected mean of $\chi^{2}$ association statistics $\left(\lambda_{\text {mean }}\right)$ is

$$
\lambda_{\text {mean }}(L R)=1+N h_{g}^{2} / M
$$


Regardless of the generic architecture of the trait. For MLMi, the $\lambda_{\text {mean }}$ value at marker used to construct the GRM is;

$$
\lambda_{\text {mean }}(M L M i)=1
$$

$\mathrm{M}$ represents markers and $\mathrm{N}$ is the samples, since variance component estimation will be repeated when looking at candidate marker in the regression formula. Assumptions on a set samples not related to any other artifacts population structure is more accurate. $\mathrm{N}$ denotes the number of samples, $\mathrm{M}$ denotes quantity of markers while $h_{g}^{2}$ denotes the heritability for imputed markers and/or genotyped.

A genetic relationship matrix (GRM) constructed that can better relate phenotypic variance and casual variance by applying a correlation that is specific to the sample variance, when modeling fixed effect for basis of overall covariance on random selected samples in geographical area, would achieve a better result in understanding irrigation and plant harvesting mechanisms that are more effective. This will outweigh the application of redundant and ineffective research methods in agronomical activities, and reduce false positive association of genetic variables in research into clean cane production. Ascertained case studies represent special challenges as a result of potential decline in application of concepts involving standard MLM methods from small sample sizes or high disease prevalence rate in sugarcane harvested (Sarto \& Hassuani, 2005: 59). Research into further biotechnical elements would not materially deviate from the researcher's objective of elaborating on clean cane production, but can involve deeper understanding or scientific processes that would impair the objective of the research.

In other related research findings, Paul \& Krishnamurthi (2007: 115) focused on one of India's largest sugar mills, in Nellikuppam, and tried to establish a relationship between processing sugarcane trash and producing clean renewable energy from refined cane for environmental sustainability and effective sugarcane disease control. Trash cannot be left out of the clean cane processing. Aguilar et al. (1995) as quoted by Paul \& Krishnamurthi (2007: 117) looked at balers used in addressing problems of high wear in soil content in sugarcane farms. Mist or rain also increased moisture in trash as chocking and tying setbacks from cane stalks left in sugarcane fields were identified as issues arising from baler pickups. Trails have been used in India since 1985, despite the lack of adequate transport infrastructure and low mechanization levels (Sordi \& Manechini, 2013). An increase in demand for cane trash to supplement baling required manual collection within a $15 \mathrm{~km}$ radius from the mill in Nellikuppam. According to Manohar Rao (1997) as quoted by Paul \& Krishnamurthi (2007: 118), baling has the following agronomical advantages for ratoon crop.

- Burning of trash in the field is avoided due to its removal.

- About 20 to $30 \%$ trash left can improve soil fertility and reduce sugarcane diseases.

- Post-harvest trash burnt can have an impact on germination of buds as gaps are formed in the ratoon crop.

Breeding ground for diseases like Yellow Leaf Disease (YLD) is prevalent in India (Madugula et al., 2016). Clay loom soils in District of Andhra Pradesh in India are well known for their low nitrogen contents. When measuring the length of 10 mature canes that could be milled to obtain a mean length, attention was given to the least transverse mark only. Internode lengths were calculated using formula below:

Internode length $=$ Average cane height /Average number of internodes.

(Internode Length and Average cane height were measured in centimeters only).

The use of digital balance to measure the weight of the mature canes was crucial in data collection. But the formula used did not take the weight variable into consideration, due to the use of Vernier Calipers used in measuring only the perpendicular diameter between any two of the nodes of the mature canes selected for the experiment. This negatively affected the results obtained, and "YLD is mainly transmitted through sett borne inoculum" as it was found by Madudula et al. (2016: 865). Although the study was conducted with the aim of evaluating how effective the disinfectant chemicals used in reducing inoculum load with sett treatment was, to prevent YLD, the relationship between the intensive use of nitrogen fertilizers (NF) and age of sugarcane was left out of the main investigation. Thermotherapy, meristem and hot water treatment (HWT) involving clean cane production could pave pay or future research in to methods of combating sugarcane diseases like YLD and the use of NFBs that can cause sugarcane smut disease (SSD). Lee \& Bressan (2005: 13) focused on "disease resistant" varieties and use of HWT. Pierik (1987) as quoted by Lee \& Bressan (2005: 11) did elaborate on what was considered as the 5 main clean cane production methods without viruses. These were: 
Meristem culture $\rightarrow$ Heat treatment (also known as HWT) $\rightarrow$ Adventitious shoot formation $\rightarrow$ Grafting of meristems on virus-free root stocks.

Without looking deeper into each method, HWT was least effective for treating other viruses like sugarcane mosaic virus (SMV), xanthomonas albilineans(XA) and ratoon stunning disease (RSD). Crop Genetics International in 1994 claimed to have developed techniques in which organogenesis was directly conducted directly on immature sugarcane leaf (Lee \& Bressan, 2005: Daugrois et al., 2003). This method still finds its application in soma clonally derived seed cane farms in Louisiana and Florida (in North America) for seed cane planting. Corroborating the findings with facts, NFB was first discovered by Dr. Johanna Dőbereiner, who observed the prevalence of genus Beijerinckia in most of the sugarcane fields he observed in Brazil. The findings could prove the use of nitrogen fixation of about $60 \mathrm{~kg} \mathrm{~N} / \mathrm{ha}$ in Brazil, compared to usage of $300 \mathrm{~kg} \mathrm{~N} / \mathrm{ha}$ in most other countries combined, could double output on 5.5 million hectares of sugarcane planted, and save up to 330.000 tons of nitrogen used annually by 2009 for cleaner cane cultivation in Brazil. Daugrois et al. (2003) claimed that xanthomonas albilineans(XA) is a more prevalent disease in sugarcane (in contaminated stalk) with its occurrence in 66 countries. Research was centered around tissues of disease-free cultured sugarcane plants in Guadeloupe. The X. albilineans bacteria strains had been isolated for 48 hours from symptomatic leaves in Wilbrink's medium and used in inoculating sugarcane plants. But the use of $95 \%$ ethanol and flame was not effective in disinfecting each of the strains. The use of dew on leaves early in the morning to detect X. albilineans, with only 10 quadrants from droplets in $2 \mathrm{ml}$ of pooled water on leaf surface was not sufficient. Many bacteria populations recorded (like novobiocin, cephalexin, propiconazole, cycloheximide etc...) were not relevant in establishing the prevalence of $\mathrm{X}$. albilineans, as sterilized distilled water was used in first sampling procedure to wash the two leaf parts of each block of Epiphytic X. albilineans population densities 38 days after inoculation. This resulted in reliance on data from inoculated areas that had reduced internodes. Giving priority to observations of aerial transmission only is not material enough to prove X. albilineans 13 weeks from the transplant conducted amidst the multiple interventions (Daugrois et al., 2003: 451).

Despite findings by Lee \& Bressan, (2005) on Hot Water Treatment being widely used as a means of fighting sugarcane diseases, Nitrogen Fixation Bacteria and Yellow Leaf Diseases could be reduced in Brazil by reducing the use of nitrogen fertilizers. Results from the sterilized distilled water used in testing other viruses like X. albilineans can be improved with use of data from more non-inoculated areas over an extended time frame of testing. Using 13 weeks to conduct the experiment can be insufficient to prove the disease does exist in 66 countries. This paves way for researching into alternative cost efficient ways for testing the disease traits in sub-Saharan Africa and other hot humid Equatorial Regions where sugarcane is cultivated.

Reducing soil wear and tear by using balers is more efficient than burning trash. Deterioration and delays are strongly connected, as processing must be done timeously after harvesting sugarcane. The 5 varieties of ratoon cane used by Wood (1976: 13) when looking deeper into deterioration in chopper cane over whole stalked cane still needs to be tested using bigger sample sizes. Even if mechanized methods of trash removal is still not being fully integrated into sugarcane farming, spreading and raking of trash by South Africa's IIIovo sugar company during sugarcane harvesting with use of modified road brushes, has been proven to be more efficient (Loubser, 2002: 42), and can be a more environmentally friendly approach for clean cane production.

Interpreting outcomes of testing genetic variables with agronomical research is very complex and cumbersome if the methods used are not clearly elaborated upon. Genotype-environmental relationship has not been fully integrated into advanced research strategies. Though Mixed Linear Models can better enable researchers to understand the genetic relationship between organism in an environment, the elements used to test genetic traits need to be updated and generally accepted by researchers. Yang et al., (2013: 100).

\section{Conclusions and Recommendations}

We have conducted a desk review of some of the works done in literature around the implication of clean cane production for environmental sustainability. Various techniques employed in cane production, including harvesting and the improvement overtime have also been reviewed. There is no gainsaying that much have been done in this regard but a whole lot still have to be done to make our environment save for future generations. Of particular note is green cane harvest that is statistically shown to consume more fuel than the burnt cane harvesting technique. This and many more areas highlighted in this work calls for more investigation if we must make the environment sustainable with losing values that are generated from cane production.

\section{References}

Daugrois, J. H., Dumont, V., Champoiseau, P., Costet, L., Boisne-Noc, R., \& Rott, P. (2003). Aerial contamination of sugarcane in Guadeloupe by two strains of Xanthomonas albilineans. European journal of 
plant pathology, 109(5), 445-458. Retrieved January 19, 2017, from https://www.researchgate.net/profile/J-H_Daugrois/publication/226016026_Aerial_Contamination_of_Suga rcane_in_Guadeloupe_by_Two_Strains_of_Xanthomonas_albilineans/links/56ebffa808ae24f050991096.pd $\mathrm{f}$

De Beer, A. G., Boast, M. M. W., \& Worlock, B. (1989). The agricultural consequences of harvesting sugarcane containing various amounts of tops and trash. Proc. S. Afr. Sugar Technol, 63, 108-113.

Jackson, P. A., \& Morgan, T. E. (2003). Early stage selection for commercial cane sugar (CCS) in sugarcane clones: effects of time of sampling and irrigation. Crop and Pasture Science, 54(4), 389-396. Retrieved January 20, 2017, from http://www.publish.csiro.au/cp/AR02110

Johnson, H. W., Robinson, H. F., \& Comstock, R. E. (1955). Estimates of genetic and environmental variability in soybeans. Agronomy journal, 47(7), 314-318. Retrieved January 18, 2017, from https://dl.sciencesocieties.org/publications/aj/abstracts/47/7/AJ0470070314

Lee, T. S., \& Bressan, E. A. (2005). Clean cane with nitrogen fixing bacteria. Sugar Tech, 7(1), 11-16. Retrieved January 20, 2017, from http://0-resolver.ebscohost.com.wam.seals.ac.za/openurl?sid=google\&auinit=TSG\&aulast=Lee\&atitle=Clea $\mathrm{n}+$ cane + with + nitrogen + fixing + bacteria\&id $=$ doi\%3a10.1007\%2fBF02942412\&title $=$ Sugar + Tech \&volume $=$ $7 \&$ issue $=1 \&$ date $=2005 \&$ spage $=11 \&$ site $=$ ftf-live

Loubser, R. C. (2002). Model for estimating effects of harvesting practices on factory output. In Proc S Afr Sug Technol Ass (Vol. 76, p. 42). Retrieved January 18, 2017, from http:/www.sasta.co.za/wp-content/uploads/Proceedings/2000s/2002_loubser_MODEL\%20FOR\%20ESTI MATING\%20EFFECTS.pdf

Lyne, P. W. L., Langton, M. I., Bezuidenhout, C. N., \& Smithers, J. C. (2007). Performance and economics of the illovo mechanical cane cutter. In Proc. Int. Soc. Sugar Cane Technol (Vol. 26). Retrieved January 17, 2017, from http://www.issct.org/pdf/proceedings/2007/Papers/2007\%20Lyne,\%20PERFORMANCE\%20AND\%20EC ONOMICS\%20OF\%20THE\%20ILLOVO\%20MECHANICAL\%20CANE\%20CUTTER.pdf

Madugula, S., Devi, G. U., Adilakshmi, D., Kumar, N. R., Vijayalakshmi, K., Bharatalakshmi, M., \& Reddy, B. V. (2016). Impact of Sett Disinfectants on Yellow Leaf Disease (YLD) Incidence and Yield and Growth Parameters in Sugarcane. International Journal of Bio-Resource \& Stress Management, 7(4). Retrieved January $18, \quad 2017, \quad$ from https://www.researchgate.net/profile/Suresh_Madugula4/publication/308030583_Impact_of_Sett_Disinfect ants_on_Yellow_Leaf_Disease_YLD_Incidence_and_Yield_and_Growth_Parameters_in_Sugarcane $/$ links $/ 5$ $7 \mathrm{~d} 7 \overline{9} \mathrm{c} 1 \overline{4} 08 \mathrm{ae} 60 \overline{1} \mathrm{~b} 39 \mathrm{ac} 32 \mathrm{e} 2 . \mathrm{pdf}$

McFarlane, S. A. (2003). Evaluation of Sugarcane Varieties for Resistance to Ratoon Stunting Disease. Retrieved January 18, 2017, from http://researchspace.ukzn.ac.za/handle/10413/4293

Moreira, J. R., Romeiro, V., Fuss, S., Kraxner, F., \& Pacca, S. A. (2016). BECCS potential in Brazil: Achieving negative emissions in ethanol and electricity production based on sugar cane bagasse and other residues. Applied Energy, 179, 55-63. Retrieved January 17, 2017, from http://www.sciencedirect.com/science/article/pii/S0306261916308194

Paul, H. V., \& Krishnamurthi, M. (2007). Sugarcane trash collection at the small farms in Southern India. In Proc. Int. Soc. Sugar Cane Technol (Vol. 26). Retrieved January 19, 2017, from http://www.issct.org/pdf/proceedings/2007/Papers/2007\%20Paul,\%20SUGARCANE\%20TRASH\%20COL LECTION\%20AT\%20THE\%20SMALL\%20FARMS\%20IN\%20SOUTHERN\%20INDIA.pdf

Richard, C. (2005). The impact of green cane production systems on manual and mechanical farming operations. In Proc. ISSCT (Vol. 25). Retrieved January 17, 2017, from http://www.issct.org

Sarto, C. A., \& Hassuani, S. J. (2005). Trash recovery: Baling machines. Biomass power generation: Sugar cane bagasse and trash. Programa das Nações Unidas para o Desenvolvimento, Centro de Tecnologia Canavieira, Piracicaba, Brazil, pp.57-60. Retrieved January 19, 2017, from http://www.sciencedirect.com/science/article/pii/S1364032114000537

Sordi, R. D. A., \& Manechini, C. (2013). Utilization of trash: a view from the agronomic and industrial perspective. Scientia Agricola, 70(5), 1-2. Retrieved January 20, 2017, from http://www.scielo.br/scielo.php?pid=S0103-90162013000500002\&script=sci_arttext\&tlng=es 
Wood, R. A. (1976). Cane deterioration as affected by billet size, delay in milling and other factors. Proceedings of The South African Sugar Technologists' Association-June, pp.12-17. Retrieved January 18, 2017, from http://citeseerx.ist.psu.edu/viewdoc/download?doi=10.1.1.381.5918\&rep=rep1\&type=pdf

Yang, J., Zaitlen, N. A., Goddard, M. E., Visscher, P. M., \& Price, A. L. (2014). Advantages and pitfalls in the application of mixed-model association methods. Nature genetics, 46(2), 100-106. Retrieved January 17 , 2017, from http://www.nature.com/ng/journal/v46/n2/abs/ng.2876.html

\section{Copyrights}

Copyright for this article is retained by the author(s), with first publication rights granted to the journal.

This is an open-access article distributed under the terms and conditions of the Creative Commons Attribution license (http://creativecommons.org/licenses/by/4.0/). 